\title{
Právní moc rozsudků Soudního dvora EU
}

\section{The Force of Res Judicata of Judgments of the EU Court of Justice}

\author{
Iva Fellerová Palkovská*
}

\begin{abstract}
Abstrakt
Clánek se zabývá v Cesku poněkud opomijeným tématem a sice právni moci rozsudkủ Soudního dvora EU. Nastinuje, jaký plni právni moc v evropském procesnim právu účel; pri hledáni zakotveni právni moci v pozitivnim právu zjiš̀tuje, že toto zakotveni v unijnim právu chybí, závèry v článku proto vychází predevšim z judikatury. V článku jsou dále na podkladě judikatury Soudního dvora popsány prèdpoklady pro nastoupeni úcinkư spojených s právni mocí, jakož i možnosti prolomeni jejího puisobeni. Pozornost je vènována také puisobeni právni moci v některých specifických pröpadech, konkrétně u rozsudkù vydaných v ř̈zeni o neplatnost aktu a rozhodnutí o predběžných otázkách.
\end{abstract}

\section{Klíčová slova}

Právni moc; Soudni dvir EU; rozhodnutí Soudního dvora EU; účnky rozsudkư; evropské procesní právo.

\begin{abstract}
The paper deals with in the Czech Republic rather neglected topic which is the force of res judicata of EU Court of Justice judgments. It outlines the objective that res judicata serves in European procedural law; when looking for the precise regulation of res judicata in the positive EU law it finds out that there is none, the conclusions of the article therefore come from the analysis of the case law. Furthermore, on basis of the case law of the Court of Justice the preconditions for the force of res judicata and its effects are described as are the exceptions to it. Attention is paid also to the functioning of res judicata in special instances, specifically in judgments given in annulment proceedings and in preliminary references.
\end{abstract}

\section{Keywords}

Res judicata; EU Court of Justice; Decisions of the EU Court of Justice; Effects of Judgments; European Procedural Law.

\section{Úvod}

Právní moc je pravděpodobně jednou z nejvýznamnějších vlastností, kterou mohou soudní rozhodnutí získat. Právní moc zaujímá významné místo v právním řádu a prestavuje podstatný prvek pro uplatňování práva v konkrétních prípadech. Jako takový je tento institut $\mathrm{v}$ určité formě vlastní snad všem vyspělým právním řádům, včetně právního řádu Evropské unie. Tento článek si klade za cíl prozkoumat právní moc rozhodnutí Soudního dvora EU, její účel, předpoklady pro nastoupení právní moci a její a účinky v obecných

* Mgr. Iva Fellerová Palkovská, doktorandka, Katedra mezinárodního a evropského práva, Právnická fakulta, Masarykova univerzita, Brno / Ph.D. student, Department of International and European Law, Faculty of Law, Masaryk University, Brno, Czech Republic / E-mail: 370609@mail.muni.cz 
i zvláštních prrípadech. Stručně se článek věnuje také právní moci vnitrostátních soudních rozhodnutí ve vztahu k unijnímu právu a působení zásady ne bis in idem v unijním právu.

\section{1 Účel právní moci}

Zkoumání institutu právní moci je nutné začít úvahami o jejím účelu. Účelem právní moci v nejobecnější rovině je zajištění právní jistoty ${ }^{1}$. K tomu přispívá rưznými zpơsoby. $\mathrm{V}$ prvé řadě označuje moment, kdy už je daná soudem projednávaná záležitost s konečnou platností vyřešena a ukončena. Strany tak od okamžiku nabytí právní moci soudního rozhodnutí mohou přestat upínat svou pozornost $\mathrm{k}$ řešení problému, který byl předmětem sporu, a podle výsledku řízení se podle něj mohou zařídit. Takto působí právní moc ve vztahu k právě projednávanému případu.

Vedle toho působí právní moc i na později zahájená řízení - brání totiž opětovnému projednávání téže věci a neukončitelnému zpochybňování výsledku řízení, $\mathrm{k}$ němuž by docházelo, pokud by účastníci řízení měli možnost podávat nové žaloby s předmětem, o němž již soud dříve s konečnou platností rozhodl. ${ }^{2}$ Soudy tak nejsou zatěžovány opakovaným projednáváním téže věci, a mohou se efektivně zabývat jinými věcmi. Zároveň se tak předejde situaci vzniku více sobě si odporujících rozhodnutí. ${ }^{3} T i ́ m$ právní moc zajišt'uje stabilitu právního řádu a právních vztahů a řádný výkon spravedlnosti.

Ve vnitrostátních právních řádech včetně toho českého je zpravidla jako hlavní účel právní moci vnímána ochrana individuálních práv jednotlivce, tedy ochrana před tím, aby jednotlivec byl ve stejné věci opakovaně žalován. ${ }^{4} \mathrm{~V}$ unijním právu to tak není. Důvod pro upozadění ochrany jednotlivce je ten, že unijní soudnictví není primárně určeno k ochraně práv jednotlivců, nýbrž k zajištění dodržování práva EU, jak je ostatně výslovně uvedeno v čl. 19 SEU. ${ }^{5}$

Institut podobný právní moci, respektive s obdobným účelem, je vlastní právním řádům všech právních států, tedy i členským státům Evropské unie. V jeho označení, zakotvení

1 Viz např. DVOř́́K, Bohumil. Právni moc civilních soudnich roz̧odnutí: procesní studie. Praha: C. H. Beck, 2008, s. 32.

2 Stanovisko generálního advokáta - Bot - 26 října 2010, ThyssenKrupp Nirosta GmbH proti Evropské komisi, věc C-352/09 P.

3 ZEUNER, Albrecht a Harald KOCH. Effects of Judgments (Res judicata). In: CAPELETTI, Mauro (ed.) International Encyclopedia of Comparative Law. Volume XVT Civil Procedure. Mohr Siebeck, Martinus Nijhoff Publishers, 2014, s. 11.

4 K účelu právní moci v právu obecně viz ZEUNER, Albrecht a Harald KOCH. Effects of Judgments (Res judicata). In: CAPELETTI, Mauro (ed.). International Encyclopedia of Comparative Law. Volume XVI Civil Procedure. 2014, s. 4; k účelu právní moci v českém právu viz DVOŘÁK, Bohumil. Komentár

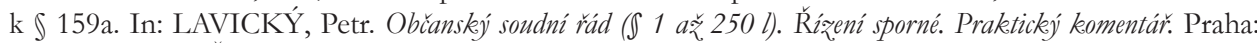
Wolters Kluwer ČR, 2016, s. 770-771.

5 GERMELMANN, Claas Friedrich. Die Rechtskeraft von Gerichtsentscheidungen in der Europäischen Union. Tübingen: Mohr Siebeck, 2009, s. 337. 
a konkrétních účincích, zejména co se týče šíře účinků a možností prolomení právní moci rozhodnutí se právní řády členských států liší ${ }^{6}$, základní účel právní moci je ale stejný, at' posuzujeme českou právní moc, německou Rechtskraft, francouzskou autorité de la chose jugée nebo anglickou res judicata. Na tomto místě je třeba z hlediska terminologického poznamenat, že zatímco česká právní věda chápe termín res judicata, neboli překážka věci rozsouzené, jako označující konkrétní projev nezměnitelnosti coby účinku právní moci ${ }^{7}, \mathrm{v}$ angličtině obecně i na unijní úrovni se jako res judicata označuje právní moc jako taková. V českých překladech unijních soudních rozhodnutí se pak také někdy používá pojem překážka věci rozsouzené, ač se dle smyslu jedná spíše o právní moc.

\section{2 Účinky a rozsah}

Účinky právní moci můžeme rozdělit do dvou základních kategorií - pozitivní a negativní ${ }^{8}$. Negativní účinek, který bývá v české právní vědě označován jako nezměnitelnost, zapříčinuje nepřípustnost opětovného projednání věci a rozhodnutí ve věci stejného předmětu, která již byla rozhodnuta. „Žaloby, které byly podány později, maji stejné účastnikey, mají stejný účel (žalobní petit, v unijní terminologii návrhové žádání - pozn. aut.) a jsou založeny na stejných diovodech [...] musí být odmitnuty jako neprǒpustné. " Negativní účinky právní moci tedy brání tomu, aby žalobce na základě stejných skutkových okolností domáhal stejného nároku a aby tak žalovaný na základě jedněch skutečností byl vícero rozsudky zavázán plnit vícekrát. ${ }^{10} \mathrm{~V}$ tomto ohledu je nezbytné určení toho, co se rozumí „stejnou věci“", resp. stejným předmětem. O tom bude pojednáno dále.

Pozitivní účinek naproti tomu značí, že výsledek pravomocně ukončeného sporu je nutno považovat za závazný v následném sporu, jehož výsledek je podmíněn výsledkem sporu prvního, přičemž předmět prvního a následného sporu není stejný. Jedná se tedy o prejudiciální závaznost. $\mathrm{V}$ tomto případě se prejudiciální závaznost neprojeví ve stejném sporu (tj. mezi stejnými stranami se stejným předmětem), nýbrž ve sporu, jehož předmět bude jiný. Výsledek prvního sporu je nutno považovat za vyřešenou předběžnou otázku (nikoli tu ve smyslu čl. 267 Smlouvy o fungování EU, dále jen „SFEU“) a pro soud rozhodující následný spor je závazný, dané skutečnosti soud nemůže posoudit jinak. ${ }^{11}$

6 K tomu podrobně GERMELMANN, 2009, op. cit., kapitoly 2, 3 a 4; nebo ZEUNER, KOCH, 2014, op. cit.

7 DVOŘÁK, 2008, op. cit., s. 58.

8 THEWES, Christian. Bindung und Durchsetzung der gerichtlichen Entscheidungen in der EU. 2003, Hamburg: Verlag Dr. Kovač, s. 118.

9 Usnesení Soudního dvora (třetího senátu) ze dne 1. dubna 1987, Alan Ainsworth a dalši proti Komisi Evropskéch společenství, spojené věci 159/84, 267/84, 12/85 a 264/85, odst. 3 a 4.

10 Srov. DVOŘÁK, 2008, op. cit., s. 55-62; nebo MACUR, Josef. Základni otázłey právni moci civilních soudních rozhodnutí. Brno: Univerzita J. E. Purkyně, 1972, s. 28-29.

11 Srov. DVOŘ́́K, 2008, op. cit., s. 62-69; MACUR, 1972, op. cit., s. 30-33. 
V konkrétních př́padech se prejudiciální závaznost projevuje následovně. Je-li Soudním dvorem uznána zákonnost správního rozhodnutí (např. Evropské komise), není možné v žalobě proti uložení pokuty navazující na předmětné správní rozhodnutí, vznášet námitku neplatnosti původního rozhodnutí. ${ }^{12}$ Stejně tak byla-li kupř́kladu v řízení o předběžné otázce či v řízení o náhradě škody Soudním dvorem konstatována neplatnost aktu přijatého orgánem Unie, zakládá tento závěr př̌kážku věci rozsouzené (jež je účinkem právní moci v následných řízeních) vưči jakýmkoli budoucím řízením, v nichž by bylo potřeba vyjít ze skutečnosti, že předmětné rozhodnutí je platné či neplatné. ${ }^{13}$

Je také potřeba uvést, že právní moc v právu EU nezahrnuje jen výrok rozhodnutí, jak je pravidlem v českém pojeti1 ${ }^{14}$, ale také nosné důvody jeho odůvodnění. Nosné důvody definuje Soudní dvůr EU jako „odìvodnèní [...] rozsudku, které je nezbytnou oporou jeho výroku a je od nèj neoddèlitelné "15 , jsou to důvody, které jsou ,potrebné k určení prèsného významu toho, co je uvedeno ve výroku'n6. Výrok tedy není možné číst samostatně, ale je třeba jej vnímat ve světle oněch nosných důvodů rozhodnutí, v němčině nazývaných tragende Entscheidungsgründe (do angličtiny je možné velmi volně přeložit jako ratio decidendi). Jedná se však o důvody, které jsou skutečně pro výrok rozhodnutí podstatné a rozhodující, právní moc nezahrnuje části, na nichž rozhodnutí ve věci nestojí (které tvoři jakési obiter dicta). ${ }^{17}$ Uvedené se nejvýrazněji projevuje $\mathrm{v}$ řízení o neplatnosti aktu nebo řízení o porušení povinnosti, kde nosné důvody rozhodnutí určují, v čem daná instituce nebo členský stát pochybili, a čeho se tedy propř́íště mají vyvarovat, slovy Soudního dvora ,je to totiž odüvodnèní, keteré na jedné strané identifikuje konkrétni ustanoveni, keteré je protiprávni, na drubé straně ukazuje presné divvody nezákonnosti zjiš̀tèné ve výroku, které musí zúčastnèná instituce brát v úvabu prì nabrazeni zurušeného ak.tu" "18.

Právní moc je základní zásadou unijního právního řádu, která je vlastní také právním řádům členských států. Soudní dvưr potvrdil, že její dodržování je ve veřejném zájmu, nejen v zájmu účastníků řízení. Důvod pro tento závěr plyne z účelu právní moci,

12 Rozsudek Soudního dvora (čtvrtého senátu) ze dne 14. prosince 1983, Klöckner-Werke AG proti Komisi Evropských společenství, věc 263/82, odst. 5-8.

13 Rozsudek Soudního dvora (velkého senátu) ze dne 9. záŕi 2008, Fabbrica italiana accumulatori motocarri Montecchio SpA (FLAMM) a Fabbrica italiana accumulatori motocarri Montecchio Technologies LLC (C-120/06 P), Giorgio Fedon \& Figli SpA a Fedon America, Inc. (C-121/06 P) proti Radě Evropské unie a Komisi Evropských spolecenství. Spojené věci C-120/06 P a C-121/06 P, odst. 123-124.

14 DVOŘÁK, 2008, op. cit., s. 87-88.

15 Rozsudek Soudního dvora (třetího senátu) ze dne 1. června 2006, P \& O European Ferries (Viqcaya) SA (C-442/03 P) a Diputación Foral de Vizcaya (C-471/03 P) proti Komisi Evropských společenství, spojené věci C-442/03 P a C-471/03 P, odst. 44.

16 Rozsudek Soudního dvora ze dne 26. dubna 1988, Asteris AE a dalši a Recké republika proti Komisi Evropskéch společenství, spojené věci 97, 193, 99 a 215/86, odst. 27.

17 TOTH, Ákos G. The Authority of Judgments of the European Court of Justice: Binding force and Legal Effects. Yearbook of European Law, 1984, roč. 4, č. 1, s. 14-18.

18 Zde ř́zení o neplatnosti aktu. Ibid., odst. 27. 
jak je nastíněn v oddílu 2 tohoto článku. Respektování právní moci je součástí unijního veřejného pořádku. ${ }^{19} \mathrm{Z}$ judikatury SDEU dále plyne, že otázka, zda projednání věci nebrání právní moc jiného rozhodnutí, mưže být soudem zkoumána i bez návrhu účastníků a v jakékoli fázi ř́zení. ${ }^{20}$

\section{Právní úprava}

Pokud bychom pátrali po výslovném zakotvení právní moci, jejích předpokladech a účincích v unijních procesních předpisech, pátrali bychom téměř marně. Statut Soudního dvora právní moc neupravuje. V české verzi jednacích řádů Soudního dvora a Tribunálu nalezneme pravidlo, podle něhož nabývají rozsudky právní moci dnem vyhlášení a usnesení dnem doručení ${ }^{21}$. Tato ustanovení se ale v jiných jazykových verzích liší - anglické, francouzské, italské i například holandské a slovenské znění na tomto místě používají termín závaznost ${ }^{22}$. V německé verzi Jednacího řádu Soudního dvora se sice použivá také termín právní moc (Rechtskeraft), německé znění Jednacího řádu Tribunálu už ovšem hovoří o tom, že se rozhodnutí stane účinné (wirksam). ${ }^{23}$ Je tedy potřeba na tato ustanovení jednacích řádů pohlížet tak, že upravují především vázanost daného soudu (Soudního dvora, resp. Tribunálu) svým rozhodnutím. O právní moci, která by měla nastat okamžikem vyhlášení rozsudku, v prrípadě rozhodnutí 'Tribunálu hovořit nelze, nebot' proti němu je př́pustný opravný prostředek; české znění je v tomto ohledu matoucí.

Právní moc přesto je institutem unijního práva. Je totiž obecnou zásadou unijního práva a jejím pramenem jsou právní rády členských států. ${ }^{24}$ Soudní dvůr EU ji takto uznává a uznává její ,zásadni význam [...], jak v právním rádu Unie, tak i ve vnitrostátních právních

19 Srov. odst. 64 až 66 stanoviska generálního advokáta Tizzana ze dne 9. února 2006 k věci $P$ \& O European Ferries (Vizcaya) SA (C-442/03 P) a Diputación Foral de Vizcaya (C-471/03 P) proti Komisi Evropských společenství, spojené věci C-442/03 P a C-471/03 P. AG Tizzano zde odkazuje na rozbor provedený GA Jacobsem ve stanovisku k věci Salzgitter (Stanovisko generálního advokáta - Jacobs - 30 března 2000, Saligitter AG proti Komisi Evropských společenstvi a Spolkové republice Německo, věc C-210/98 P.).

20 Stanovisko generálního advokáta - Roemer - 19 ř́ijna 1965, Société anonyme des laminoirs, hauts fourneaux, forges, fonderies et usines de la Providence a dalši proti Vysokému úradu ESUO, spojené věci 29, 31, 36, 39 až 47, 50 a 51-63; nebo také rozsudek Soudního dvora (třetího senátu) ze dne 1. června 2006, P \& O European Ferries (Vizcaya) SA (C-442/03 P) a Diputación Foral de Vizcaya (C-471/03 P) proti Komisi Evropských společnství, spojené věci C-442/03 P a C-471/03 P, odst. 45). Viz také TOTH, 1984, op. cit., s. 8-9.

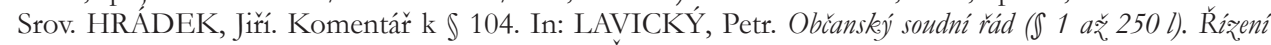
sporné. Praktický komentár. Praha: Wolters Kluwer ČR, 2016, s. 431-433.

21 Čl. 91 Jednacího řádu Soudního dvora (dále jen „JŘSD“) a čl. 121 Jednacího řádu Tribunálu (dále jen ,JR'T"r).

22 Binding nature, force obligatoire, effetti vincolanti, verbindende kracht, záväznost'.

23 K různým jazykovým verzím viz také GERMELMANN, 2009, op. cit., s. 333-334.

24 Také stanovisko generálního advokáta - Tizzano - 9 února 2006, P \& O European Ferries (Vizcaya) SA (C-442/03 P) a Diputación Foral de Vizcaya (C-471/03 P) proti Komisi Evropských společenství, spojené věci C-442/03 P a C-471/03 P, odst. 66. 
rádech ${ }^{\text {¿25 }}$, což ve svých rozhodnutích opakovaně připomíná. Coby obecná právní zásada společná právním řádům členských států je zakotvena na úrovni primárního práva. V jednotlivých členských státech se právní úprava právní moci a z toho plynoucí účinky přirozeně liší, není tak možné její obsah dovozovat čistě jen z vnitrostátních pravidel toho kterého státu a je třeba jí přisuzovat specifický unijní význam. Přes výše uvedené dochází Germelmann k závěru, že právní moc na unijní úrovni je patrně nejvýrazněji ovlivněná svým francouzským ekvivalentem autorité de la chose jugée $e^{26}$. Soudní dvůr uznává právní moc jako obecnou zásadu unijního právu a uznává její „zásadní význam [...], jak v právním rádu Unie, tak i ve vnitrostátnich práunich rádech “27.

\section{Definice právní moci v unijním právu}

V judikatuře Soudního dvora EU je právní moc tradičně definována jako vlastnost znemožňující soudu znovu rozhodnout spor mezi stejnými účastníky, který se týká stejného předmětu a je založen na stejných důvodech ${ }^{28}$. Co se týče konkrétního vymezení předpokladů a účinků v obecných i zvláštních príípadech, je právní moc rozhodnutí Soudního dvora EU prozatím do hloubky nepř́liš popsanou a projudikovanou oblastí. Odborné literatury jdoucí dostatečně do hloubky tohoto tématu je nemnoho a ze samotných rozhodnutí SDEU je sice možné leccos dovodit, lze se ovšem ztotožnit s názorem Germelmanna, že SDEU upřednostňuje ad hoc řešení jednotlivých př́padů před ucelenějším uchopením institutu právní moci a jejích účinků. ${ }^{29}$

Soudní dvůr ani jeho generální advokáti výslovně nepojmenovávají materiální a formální stránku ${ }^{30}$, která se váže k právní moci. Formální stránku, tedy nemožnost rozhodnutí napadnout opravnými prostředky, chápou jako inherentní znak právní moci, resp. jako její předpoklad, a materiální stránku, tedy nemožnost v soudním řízení rozhodnout opětovně o témže předmětu, chápou jako účinek právní moci.

$\mathrm{K}$ naplnění formální stránky právní moci dochází v okamžiku, kdy rozhodnutí nelze napadnout opravnými prostředky. Vzhledem ke specifické povaze unijního soudnictví a k tomu, že ve většině případů je řízení jednoinstanční, k němu dochází vyhlášením

25 Stanovisko generálního advokáta - Bot - 26 října 2010, ThyssenKrupp Nirosta GmbH proti Evropské komisi, věc C-352/09 P, odst. 130.

26 GERMELMANN, 2009, op. cit., s. 337.

27 Stanovisko generálního advokáta - Bot - 26 října 2010, ThyssenKrupp Nirosta GmbH proti Evropské komisi, věc C-352/09 P, odst. 130.

28 Rozsudek Soudního dvora ze dne 15. ledna 1987, Alan Ainsworth a dalši proti Komisi a Radě Evropských společenství, spojené věci 271/83, 15, 36, 113, 158, 203/84 a 13/85; Rozsudek Soudu prvního stupně (třetího senátu) ze dne 13. února 2003, Karl L. Meyer proti Komisi Evropských společenstuí, věc T-333/01, odst. 23.

29 GERMELMANN, 2009, op. cit., s. 323.

30 K chápání formální a materiální stránky právní moci v českém prostředí viz SVOBODA, Karel, Renáta ŠÍNOVÁ a Klára HAMULÁKOVÁ. Civilni proces: obecná část a sporné rízení. Praha: C. H. Beck, 2014, s. 331-332; také MACUR, 1972, op. cit., s. 25-27. 
rozsudku, nebo doručením usnesení. Pouze v případech žalob, kdy v prvním stupni rozhoduje Tribunál, je př́ipustný kasační opravný prostředek k Soudnímu dvoru ${ }^{31}$ a k naplnění formální stránky právní moci pak dochází bud’ až marným uplynutím lhůty k podání kasačního opravného prostředku, nebo v případě, že kasační opravný prostredek byl podán, v souvislosti s vydáním rozhodnutí Soudním dvorem - odmítavým usnesením nebo zamítavým rozsudkem. Podání kasačního opravného prostředku nemá odkladný účinek ${ }^{32}$, právní moci tak rozhodnutí nabude později, než nastane jeho vykonatelnost.

\section{Předpoklady pro vznik př̌kážky věci pravomocně rozhodnuté}

Pro vznik překážky věci rozsouzené plynoucí z principu právní moci jsou určující tři prvky - strany sporu, předmět sporu, jehož součástí je i návrhové žádání (petit), a důvody tvrzeného nároku. ${ }^{33}$

Vymezení stran sporu je zpravidla možné bez větších obtíží. Prakticky obtížnější je vymezení druhých dvou prvků - předmětu sporu a odůvodnění. V tomto ohledu je podstatné, že předmět sporu je určen jak otázkami skutkovými, tak právními. ${ }^{34}$ Tomu odpovídá i požadavek jednacích řádů unijních soudů v žalobě uvést jednak skutkové okolnosti prrípadu, jednak právní zhodnocení případu. ${ }^{35}$ Soudní dvůr proto po žalobcích důsledně vymezení skutkových okolností i právních argumentů vyžaduje, přičemž svůj postup odůvodňuje nutností zajištění právní jistoty a řádného výkonu spravedlnostiin ${ }^{36}$ Vymezení skutkové i právní v žalobě je z hlediska právní jistoty a řádného výkonu spravedlnosti podstatné proto, že umožňuje Soudu rychle vydat správné rozhodnutí, a protože v rozsahu takto vymezeného předmětu rrízení vzniká ve vztahu k dalším řízením překážka věci rozsouzené.

Důraz na význam nejen skutkových, ale i právních otázek pro posouzení totožnosti předmětu je patrný z vyjádření GA Tizzana „Musím skutečně zdiraznit, že pojem „tentíž

31 Čl. 256 odst. 1 SFEU.

32 Čl. 278 SFEU, s výjimkou případu, kdy Tribunál rozhodne o zrušení nařízení - tam nastává právní moc až po uplynutí lhůty k podání opravného prostředku nebo po jeho zamítnutí (čl. 60 Statutu SDEU).

33 Srov. náležitosti žaloby v čl. 120 JŘSD, kde se požaduje jak uvedení skutkového stavu, tak právní zhodnocení.

34 GERMELMANN, 2009, op. cit., s. 365; REILING, Michael. Streitgegenstand und Einrede der ,res iudicata" in Direktklageverfahren vor den Gemeinschaftsgerichten. In: Europäische Zeitschrift für Wirtschaftsrecht. 2002, s. 136. Dostupné z: http://www.beck-online.beck.de

35 Čl. 120 JŘSD, čl. 76 Jř́T.

36 „Skutečnosti uvedenév žalobě musí být dostatečné jasné a prèsné, aby umožnily žalovanému prïpravit svou obranu a Soudu vydat roz̧hodnutí, pokud možno bez. dalšich podpiorných skutečností. Za úcelem zajišténi právní jistoty a rádného výkonu spravedlnosti, má-li být žaloba prĭpustná, musi být základni skutkové okolnosti a právni argumenty, na kterých je založena, zjevné ze samotnébo podání, mohou být stručné, pokud jsou koherentni a srozumitelné. "Usnesení Soudu prvního stupně (prvního senátu) ze dne 29. listopadu 1993, Casper Koelman proti Komisi Evropských společenství, věc T-56/92, odst. 21. 
predmèt" „nemůže být omezen na formálni totožnost obou otázek" “ a dále pokračuje, že podstatná je „totožnost právni otázky, k.terá byla položena soudu. "

Totožnost právních otázek je ale potřeba zkoumat nejen na základě žalobcem podaného návrhu, ale především podle obsahu odůvodnění rozsudku. Není možné se dovolávat nemožnosti znovu projednat spor založený na určité právní otázce, pokud o ní Soudní dvůr dosud nerozhodoval. Přitom roz̧hodování je třeba vnímat tak, že se danými právními otázkami skutečně zabýval, tedy že byly předmětem sporu, strany řízení měly možnost se k ní vyjádřit ${ }^{38}$ a Soudní dvi̊r ve vztahu k nim pak učinil závěr, který měl vliv na výsledek sporu. Nestačí, pokud byla předmětná otázka součástí žaloby (nebo byla jednou z položených předběžných otázek), ale vzhledem k posouzení jiných právních otázek se jí Soudní dvưr nezabýval.

Za typický př́iklad můžeme označit případ Artegodan proti Komisi ${ }^{39}$, tj. situaci, kdy je v žalobě navrhováno zrušení právního aktu pro nedostatek pravomoci orgánu, který jej vydal, a zároveň (pro př́pad, že by soud rozhodl, že dotyčný orgán měl pravomoc napadený akt vydat) jsou v žalobě uvedeny i jiné věcné důvody, pro které by akt měl být zrušen (nap̌r. nedodržení procesních postupů či nenaplnění hmotněprávních podmínek). Pakliže soud rozhodne, že dotyčný orgán neměl k vydání aktu pravomoc, nebude se zabývat dalšími důvody pro možnou neplatnost aktu. $V$ takovém případě se překážka věci rozsouzené plynoucí z právní moci uplatní jen vưči námitce nedostatku pravomoci, nikoli vi̊či dalším důvodům uplatněným v žalobě.

Na druhou stranu pokud Soudní dvưr určitou část právního aktu potvrdí, nelze se v dalším soudním řízení ze stejných důvodů domáhat zrušení jiného aktu, který je pouhým zopakováním aktu prvotního. Tato situace nastala v případě Emilia Barge proti Vysokému úradu ESUO, kde se jednalo o to, že Soudní dvůr v předcházejícím rozhodnutí jednu část aktu zrušil a druhou potvrdil. Vysoký úřad následně vydal pro další období akt, který byl v rozhodné části identický jako nezrušená část prvního aktu. Navrhovatelka se domáhala zrušení tohoto novějšího aktu, návrh byl ale Soudem prohlášen za nepřípustný ve vztahu k té části, která byla pouhým zopakováním aktu dřívějšího. ${ }^{40}$

Totožnost právních otázek je potřeba zkoumat detailně. Z praxe Soudního dvora je patrná ochota zkoumat totožnost, resp. odlišnost právních otázek do detailu, pokud

37 GA Tizzano v této větě cituje rozsudek SDEU ve věci Gubish Maschinenfabrik. Stanovisko generálního advokáta - Tizzano - 9 února 2006, P \& O European Ferries (Vizcaya) SA (C-442/03 P) a Diputación Foral de Vizcaya (C-471/03 P) proti Komisi Evropských společenstuí, spojené věci C-442/03 P a C-471/03 P.

38 Byt' v případě ThyssenKrupp Nirosta proti Komisi generální advokát Bot argumentoval, že strany ve skutečnosti na danou právní otázku reagovat neměly možnost.

39 Rozsudek Soudního dvora (třetího senátu) ze dne 19. dubna 2012, Artegodan GmbH, dalši účastnice rízenení Evropská komise a Spolková republika Némecko, věc C-221/10 P.

40 Rozsudek Soudního dvora ze dne 16. února 1965, Emilia Barge, vdova po p. Leone, proti Vysokému úradu ESUO, věc 14-64; dále také LASOK, K. P. E. The European Court of Justice: Practice and Procedure. 2. vyd. London: Butterworths, s. 219. 
je v řízení namítáno, že o věci již bylo pravomocně rozhodnuto. V řízení Komise proti Lucembursku $u^{41}$, které se týkalo namítaného porušení povinností Lucemburska plynoucích ze směrnice o ochraně vod před znečištěním dusičnany ze zemědělských zdrojů, Lucembursko namítalo překážku věci rozsouzené ve vztahu $\mathrm{k}$ některým žalobním bodům. Jednalo se totiž v pořadí již o druhé řízení o porušení povinnosti, které Komise vưči Lucembursku kvưli porušení povinností plynoucích z této směrnice zahájila, a i v předešlém řízení o porušení povinnosti rozhodl Soudní dvưr. V tomto (pozdějším) řízení tak Soudní dvưr přezkoumával body žaloby a konstatoval, že předešlé rrízení se týkalo nedodržení jiných ustanovení směrnice a že tudíž ,v projednávané věci neexistuje mez̧i obèma prǐpady v podstatě žádná totožnost z blediska skutkového a právního“. Zásada překážky věci rozsouzené tak nebyla porušena.

\section{Možnosti prolomení právní moci}

Byt' právní moc značí nezměnitelnost rozhodnutí, neplatí to absolutně. Ve stanovených př́padech lze právní moc i v unijním právu prolomit. Jedním z těchto stanovených případů je obnova rrízení. Obnovit rrízení může Soudní dvưr na návrh účastníka řízení za splnění několika podmínek - musela vyjít najevo nová skutková okolnost, tedy nikoli právní otázka. Tato okolnost musela nastat před vyhlášením rozsudku, přičemž nemohla být známa Soudní dvoru ani tomu účastníkovi řízení, který obnovu navrhuje. Byla-li Soudem zmíněna či vzata do úvahy, nejedná se o novou skutečnost. To platí i v případě, že tato skutečnost byla Soudu známa, i když Soudem v ř́zení zmíněna nebyla, a to at' byla tato vědomost náhodná či nikoli. ${ }^{42}$ Zároveň musí být nová skutečnost takového charakteru, že by mohla vést k jinému výsledku řízení u Soudního dvora, kdyby o ní Soudní dvưr věděl. ${ }^{43}$ Pokud by nová skutečnost nemohla vést ke zpochybnění stěžejního závěru Soudu a nemohla tak vést k odlišnému rozhodnutí, nebyla by obnova řízení přípustná. ${ }^{44}$ Dále je pro podání návrhu na obnovu řízení stanovena subjektivní lhưta 3 měsíců a objektivní desetiletá lhůta.

Ze systematického zařazení ustanovení o obnově řízení ve Statutu Soudního dvora a Jednacího řádu Soudního dvora, resp. Tribunálu, jakož i z judikatury Soudního dvora k nim plyne, že obnova řízení není řádným opravným prostředkem, nýbrž je opravným prostředkem mimořádným. Na rozdíl od kasačního opravného prostředku je obnovou

41 Rozsudek Soudního dvora (velkého senátu) ze dne 29. června 2010, Evropská komise proti Lucemburskému velkovévodstuí, věc C-526/08.

42 Odstavec 2 a 3 rozsudku Soudního dvora (druhého senátu) ze dne 10. ledna 1980, Arturo Bellintani a dalši proti Komisi Evropských společenství, věc 116/78 rév.

43 Čl. 44 Statutu SDEU ve spojení s čl. 159 Jednacího řádu SD, resp. čl. 169 Jednacího řádu Tribunálu. Blíže také LENAERTS, Koen, Ignace MASELIS a Kathleen GUTMAN. EU Procedural Law, Oxford: Oxford University Press, 2014, s. 854-857.

44 Odst. 14-18 usnesení Soudu prvního stupně (druhého senátu) ze dne 1. července 1994, Norsk Hydro A/S proti Komisi Evropskéch společenství, věc T-106/89 Rév. 
řízení možné zvrátit rozhodnutí, které již nabylo právní moci. ${ }^{45}$ Právě proto jsou pro př́ipustnost obnovy řízení stanoveny prrísné podmínky, na jejichž striktním naplnění Soudní dvưr trvá. ${ }^{46}$

Druhou možností, jak je možné prolomit právní moc rozhodnutí, je přezkum. Ten se uplatňoval pouze vưči rozhodnutím Tribunálu, kde Tribunál rozhodoval o opravném prostředku proti rozhodnutí specializovaného soudu (Soudu pro veřejnou službu $)^{47}$. Po reformě Tribunálu je tato možnost pouze teoretickou. O potřebě provedení přezkumu rozhodoval specializovaný senát Soudního dvora na návrh prvního generálního advokáta, v prípadě kladného rozhodnutí o provedení přezkumu tentýž senát rozhodoval následně ve věci samé ${ }^{48}$. Podmínka pro př́pustnost přezkumu je stanovena př́mo SFEU jako vážné ohrožení jednoty nebo souladu práva Unie ${ }^{49}$. Již z tohoto znění je zř̉ejmé, že se jedná o vskutku mimořádný opravný prostředek, jenž je rezervován pouze pro výjimečné př́pady, k čemuž Soudní dvưr odpovídajícím způsobem přistupuje, resp. přistupoval..$^{50}$ Podstatné je, že se na rozdíl od obnovy řízení jedná o přezkum omezený na právní otázky.

\section{Specifické př́ípady právní moci v unijním soudnictví}

Právní moc rozhodnutí se projevuje rozdílně v závislosti na tom, v jakém typu rrízení bylo rozhodnutí vydáno.

\subsection{Rozhodnutí v řízení o neplatnost aktu}

Prohlásí-li Soudní dvůr právní předpis za neplatný, má právní moc jeho rozhodnutí absolutní právní účinky, působí erga omnes. ${ }^{51}$ Rozhodnutí prohlašující neplatnost je závazné v tom smyslu, že právní předpis je zrušen a dále na jeho základě nevznikají jednotlivcům práva a povinnosti. Tyto účinky rozhodnutí prohlašujícího neplatnost jsou napříč judikaturou i doktrínou akceptované. Důvod je v tomto případě jasný. Cílem řízení je kontrola unijního zákonodárce, toho, zda byly dodrženy předepsané legislativní postupy, zda nebyla př̌kročena pravomoc Unii svěřená členskými státy, nebo zda je právní akt

45 Odstavec 16 rozsudku Soudu prvního stupně (třetího senátu) ze dne 28. října 2004, Herbert Meister proti Úradu pro harmonizaci na vnitřním trbu, věc T-76/03.

46 Odstavec 3 rozsudku Soudního dvora (druhého senátu) ze dne 10. ledna 1980, Arturo Bellintani a dalsíproti Komisi Evropských společenstuí, věc 116/78 rév.

47 SFEU předpokládá také možnost přezkumu rozhodnutí Tribunálu o předběžných otázkách, nicméně dosud Tribunálu Statutem SDEU nebyla svěřena pravomoc o předběžných otázkách rozhodovat.

48 Čl. 191 a 195 JŘSD.

49 Čl. 256 odst. 2 a 3 SFEU.

50 LENAERTS, MASELIS, GUTMAN, 2014, op. cit., s. 659-661.

51 Viz také WÄGENBAUR, Bertrand. Court of Justice of the European Union: commentary on statute and rules of procedure. München: C. H. Beck, 2013, s. 123. 
v souladu s předpisy vyšší právní síly a zda neporušuje lidská práva. Obdobně to platí i pro rušení individuálních právních aktů. Z výše uvedeného a z povahy řízení o neplatnosti aktu plyne, že má-li být zaručeno dodržování unijního práva (čl. 19 Smlouvy o EU, dále jen „SEU“), musí mít rozsudek rušící právní předpis závaznost erga omnes. To ostatně není nic neobvyklého ani v českém právu - nálezy Ústavního soudu rušící právní předpisy jsou také závazné pro všechny. Absolutní právní moci při tom nabývá nejen výrok rozhodnutí Soudu, ale také nosné důvody rozhodnutí. ${ }^{52}$ Unijní orgány se musí pro příště těmito důvody řídit.

Zrušení právního aktu se projeví ve sféře všech dotčených subjektů. Pokud se ovšem jedná o několik právních aktů, které ač jsou skutkově i právně totožné, mají jiné adresáty - typicky v prrípadě rozhodnutí v kartelových věcech - je situace jiná. V těchto př́padech se musí každý adresát dovolávat neplatnosti rozhodnutí sám. Je-li jedno z takových rozhodnutí zrušeno, právní moc ostatních, které jsou určeny jiným subjektům a které nebyly napadeny, zůstává nedotčena a jsou tak nadále platné. ${ }^{53}$ Rozhodnutí rušící akt sice má platnost erga omnes, nemůže se ale vztahovat na akt, který napaden nebyl, ač by byl stižen stejnou vadou jako zrušený akt. ${ }^{54}$ Odůvodnění rozhodnutí totiž není závazné pro osoby, které nebyly účastníky řízení a ve vztahu k nimž rozsudek nemohl nic změnit. Požadavek na zachování právní jistoty zde převažuje požadavek zákonnosti vydaných rozhodnutí. ${ }^{55}$

Stejně tak se zrušení jednoho právního aktu nedotýká právní moci dalších aktů, které jsou na něm založeny. Mưže se ale stát, že neplatnost může návazná rozhodnutí učinit slovy Soudního dvora neúčinnými a bezpředmětnými ${ }^{56}$. Pokud je pak návazné rozhodnutí napadeno žalobou na neplatnost, Soud jej automaticky prohlásí za neplatné, aniž by se zabýval dalšími námitkami. ${ }^{57,58}$

Právní moc rozsudku zamítajícího žalobu na neplatnost oproti výše popsané situaci má rozdílné účinky - je relativní. Platí, že automaticky neznamená zákonnost aktu, tedy že by v budoucnu nemohl být zrušen z jiných důvodů.

52 GERMELMANN, 2009, op. cit., s. 398-399.

53 GERMELMANN, 2009, op. cit., s. 399.

54 Rozsudek Soudního dvora ze dne 14. záři 1999, Komise Evropských společenstvíproti AssiDomän Kraft Products AB, Iggesunds Bruk AB, Korsnäs AB, MoDo Paper AB, Södra Cell AB, Stora Kopparbergs Bergslags AB a Svenska Cellulosa $A B$, věc C-310/97 P.

55 TRIDIMAS, Takis. The general principles of EU law. 2 vyd. Oxford: Oxford University Press, 2006, s. 31-32.

56 Rozsudek Soudního dvora ze dne 21. prosince 1954, Francousská republika proti Vysokému úradu ESUO, věc $1-54$, s. 33.

57 Rozsudek Soudu prvního stupně (prvního senátu) ze dne 22. řijna 2002, Schneider Electric SA proti Komisi Evropských společenstuí, věc T-77/02.

58 GERMELMANN, 2009, op. cit., s. 400. 
Pokud někdo napadne akt z důvodů, které již Soud ve vztahu k platnosti daného aktu jednou posuzoval, Soud žalobu zamítne. Potenciálním žalobcům ale nebrání nic v tom navrhovat Soudu zrušení aktu z důvodů jiných. ${ }^{59}$

\subsection{Rozhodnutí o předběžné otázce}

Rozhodnutí o předběžné otázce je z hlediska účinků právní moci asi nejzajímavější. Je otázkou, zdali je možné v tomto případě vůbec o právní moci rozhodnutí uvažovat. ${ }^{60}$ Sám Soudní dvưr ale ve vztahu k rozhodnutím o předběžných otázkách o právní moci hovoŕí. ${ }^{61}$

Rozhodnutí o předběžné otázce se nepochybně okamžikem vyhlášení stává konečným, je nezměnitelné. Soudní dvůr je jím vázán, stejně tak strany. Není možné proti němu podat opravný prostředek. I rozhodnutí o předběžné otázce tak mají účinek nezměnitelnosti, at' se jedná o rozhodnutí výkladová nebo o platnosti. Na otázku, zda mají také prejudiciální závaznost, není zcela jednoduchá odpověd’. Na tomto místě je třeba rozlišit absolutní a relativní účinky právní moci. ${ }^{62}$ Absolutní účinky právní moci, tedy působení erga omnes, se v př́padě rozhodnutí o předběžných otázkách neuplatní. Rozhodnutí o předběžných otázkách je z hlediska účinků právní moci specifické tím, že účinky jsou striktně relativní, omezené pouze daný případ, který je soudem projednáván, a zároveň na onu předběžnou otázku, která je Soudnímu dvoru kladena. Závaznost rozhodnutí o předběžných otázkách je proto namístě vnímat spíše jako precedenční, než jako prejudiciální závaznost.

Pokud se zaměříme na rozhodnutí o předběžných otázkách týkajících se výkladu, je nesporné, že Soudním dvorem zodpovězená předběžná otázka, tedy podaný výklad určitého ustanovení práva EU, nenabývá absolutních účinků právní moci, neplatí tedy erga omnes a nemá tak v podstatě sílu zákona. Pokud bychom výkladovým rozhodnutím přiznali účinek erga omnes, znamenalo by to v podstatě, že by takový výklad Soudu nebylo v budoucnu prakticky možné změnit ${ }^{63}$, protože právní moc je možné prolomit

59 Rozsudek Soudního dvora ze dne 9. listopadu 1995, Atlanta Fruchthandelsgesellschaft mbH a dalši proti Bundesamt für Ernährung und Forstwirtschaft, Frankfurt am Main, Německo, věc C-465/93.

60 Srov. LASOK, K. P. E. The European Court of Justice: Practice and Procedure. 2. vyd. London: Butterworths, s. $220-221$.

61 Viz např. rozhodnutí Wünsche, odst. 13. Usnesení Soudního dvora ze dne 5. března 1986, Wünsche Handelsgesellschaft GmbH \& Co. proti Spolkové republice Nèmecko, věc 69/85. Anglická verze rozhodnutí používá nepřesný termín „conclusively“, v ostatních jazykových verzích se objevuje označení právní moci, v německé verzi (která je autentická) je použit termín Rechtskraft, ve francouzské autorité de la chose jugée atd.

62 Srov. také Rozsudek Soudního dvora (třetího senátu) ze dne 1. června 2006, P \& O European Ferries (Vizcaya) $S A(C-442 / 03$ P) a Diputación Foral de Vizcaya (C-471/03 P) proti Komisi Evropských společenství, spojené věci C-442/03 P a C-471/03 P.

63 Pouze změnou vykládaného pramene práva, což je v př́padě primárního práva značně zdlouhavý a politicky i právně komplikovaný proces. 
pouze z úzce stanovených důvodů. Takový postoj ale Soudní dvůr ve vztahu ke svým rozhodnutím o předběžných otázkách nezastáváa4, ostatně ani ustanovení Smluv takovou pravomoc Soudnímu dvoru neprriznávají. Nadto by takto silná závaznost rozhodnutí o předběžných otázkách týkajících se výkladu silně kontrastovala s omnoho slabší závaznosti rozhodnutí o předběžných otázkách týkajících se platnosti právních předpisů, ač z textu Smluv rozhodně neplyne, že by mezi nimi měl být takový rozdíl. Soudní dvưr se ale od svého výkladu odchýlit může a v praxi tak činí. Tento př́stup je typický pro účinky precedenční, nikoli pro právní moc.

Prejudiciální závaznost je nutné vnímat jako úzce spojenou se skutkovým rámcem předběžné otázky a se stranami sporu v původním řízení před vnitrostátním soudem.

Možnost soudu, který rozhoduje spor v původním řízení, položit novou předběžnou otázku na výše uvedeném nic nemění. Bude-li otázka z hlediska obsahu identická, bude Soudem prohlášena za nepř́pustnou a nebude se jí věcně zabývat. Vnitrostátní soudy vedoucí spor $\mathrm{v}$ původním řízení však mohou podat předběžnou otázku, jejímž předmětem bude vyjasnění obsahu nebo dosahu pưvodního rozhodnutí, nebo jiná právní otázka, která posléze vyšla najevo, nebo i v případech, kdy vnitrostátní soud předloží nové skutečnosti a úvahy, které mohou Soudní dvưr přesvědčit dát jinou odpověd', než byla obsahem předchozího rozhodnutí o předběžné otázce. ${ }^{65}$ Tyto situace k prolomení právní moci již vydaného rozhodnutí o předběžné otázce nevedou, v pořadí druhé řízení o předběžné otázce totiž v takovém prrípadě bude mít jiný předmět. Předmět je nutno vnímat nejen jako skutkové okolnosti původního sporu, ale také v právním smyslu jako onu otázku - konkrétní otázku, která se bude vázat na výklad konkrétního ustanovení některého z pramenů unijního práva a bude spojena se skutkovými okolnostmi sporu v původním řízení.

Soudní dvưr např́klad ve věci Eierkontor ${ }^{66} \mathrm{v}$ jednom vnitrostátním soudním řízení připustil opětovnou předběžnou otázku se stejným předmětem, přičemž ponechal na předkládajícím soudu, aby zvážil, zda je k řádné aplikaci rozsudku Soudního dvora opětovné položení předběžné otázky potřebné, nebo zda již vydaný rozsudek Soudního dvora předmětnou otázku dostatečně osvětlil. Předběžná otázka je tedy prŕípustná i v situaci, kdy vychází ze stejného řízení a má stejný předmět jako již Soudním dvorem jednou zodpovězená předběžná otázka, shledá-li předkládající soud její položení potřebným. Prejudiciální závaznost se proto uplatní jen ve velmi úzkém prostoru. V ostatních př́padech můžeme hovořit spíše o závaznosti precedenční.

64 I GA Lagrange ve stanovisku k věci Da Costa Soudní dvůr od přiznání takových účinků svým rozhodnutím odrazoval. Stanovisko generálního advokáta - Lagrange - 13 března 1963, Da Costa en Schaake NV, Jacob Meijer NV, Hoechst-Holland NV proti Administration fiscale néerlandaise, spojené věci 28 až 30-62.

65 Rozsudek Soudního dvora (pátého senátu) ze dne 11. června 1987, Pretore di Salò proti X, věc 14/86, odst. 12.

66 Rozsudek Soudního dvora ze dne 4. dubna 1968, Firma Milch-, Fett-und Eierkontor GmbH proti Hauptzollamt Saarbrücken, věc 25-67. 
Rozhodnutí o předběžných otázkách týkajících se platnosti unijního právního předpisu, které jeho platnost nezpochybní, má stejné účinky jako zamítavé rozhodnutí v řízenî o neplatnost. Napadený právní akt zưstává nadále platný a další předběžné otázky namítající neplatnost předpisu ze stejných důvodů budou zamítnuty. ${ }^{67}$

Účinky rozhodnutí o předběžné otázce, které naopak shledá právní předpis neplatným, se od účinků rozhodnutí v řízení o neplatnost aktu liší. Cestou rozhodnutí v rúzení předběžné otázce nemůže být právní předpis zrušen, zůstává nadále platnou součástí unijního právního řádu. Je-li rozhodnuto o neplatnosti, rozsudek je automaticky závazný pouze pro předkládající soud rozhodující spor v původním řízení, účinky jeho právní moci jsou tedy relativní. Nicméně dle ustálené judikatury Soudního dvora počínaje rozsudkem ve věci International Chemical Corporation platí, že rozhodnutí o předběžné otázce vyslovující neplatnost aktu je dostatečným důvodem pro to, aby soudy členských států daný právní předpis považovaly za neplatný i pro účely jiných řízení a neaplikovaly jej, aniž by musely položit novou předběžnou otázku (byt' i v tomto př́padě mají možnost ji položit). De iure tedy jeho závaznost pưsobí relativně, de facto pưsobí absolutně. ${ }^{68}$ I zde je prejudiciální závaznost nutné vnímat velmi úzce. Jako nepř́ípustná z důvodu právní moci předcházejícího rozhodnutí by snad byla pouze předběžná otázka, která by byla položena stejným soudem ve stejném sporu a byla identického znění. To je ale př́pad spíše teoretický - nelze patrně rozumně předpokládat, že by vnitrostátní soud položil Soudnímu dvoru zcela identickou předběžnou otázku bez dalšího vysvětlení. Pokud předkládající soud předběžnou otázku odůvodní jinak, načrtne jiné úvahy, které by mohly ovlivnit posouzení Soudem, nebude takový postup v rozporu s právní mocí předešlého rozhodnutí, jelikož odlišnou formulací předběžné otázky bude mít řízení jiný předmět a nebude tak naplněna podmínka pro uplatnění př̌kážky věci rozsouzené plynoucí z principu právní moci.

\section{Rozlišení právní moci rozhodnutí a precedenčního účinku}

Právní moc rozhodnutí a precedenční účinek mají v obecné rovině podobné projevy. Obě způsobují to, že o věci, která již byla soudem rozhodnuta, již nebude rozhodováno znovu. Při bližším prozkoumání je však mezi těmito dvěma zásadami řada podstatných rozdílů. Ač nejobecnějším účelem obou zásad je zachování právní jistoty, u každé se to projevuje jiným způsobem.

Právní moc cílí především na definitivní ukončení konkrétního sporu. Tato věc pak nebude předmětem dalšího soudního rozhodování a to ani opětovně v identické věci, ani v jiných řízeních mezi týmiž stranami, které závisí na výsledku původního ř́izení

67 Rozsudek Soudního dvora ze dne 9. listopadu 1995, Atlanta Fruchthandelsgesellschaft mbH a dalši proti Bundesamt für Ernährung und Forstwirtschaft, Frankfurt am Main, Německo, věc C-465/93.

68 GERMELMANN, 2009, op. cit., s. 408. 
(prejudicialita). Možnosti prolomení právní moci jsou zpravidla stanoveny předem právními předpisy, na unijní úrovni můžeme hovořit např́iklad o obnově řízení, přičemž jednotlivé možnosti prolomení právní moci mají stanovené podmínky, za kterých k němu může dojít. Je-li soudu předložena věc pravomocně ukončená, je nové meritorní rozhodnutí této věci nepř́pustné, bude tedy odmítnuto z procesních důvodů. Právní moc tedy působí z hlediska časového primárně dozadu, k ukotvení výsledku již rozhodnuté věci. ${ }^{69}$ Precedenční účinek naproti tomu cílí spíš na stanovení určitého výkladu práva, tedy na dosažení právní jistoty dotvořením (případně také vytvořením) určitého právního pravidla, které bude dále dodržováno. Precedenční účinek rozhodnutí přispívá, na rozdíl od právní moci, k vývoji v právu. Díky němu je možné v právu docílit změny, aniž by se změnila textace právních předpisů. Tím směřuje především do budoucna. Právní moc tento účinek nemá. Pro uplatnění precedenčního účinku není nutná identita př́ípadu, ale podobnost v podstatných rysech. Prolomit, či spíše překonat stávající precedent obecně je možné a to i v unijním právu. Pravidla pro překonání precedentu v právních předpisech nenalezneme, plynou především z judikatury, případně pak mohou být dotvořena doktrínou. Nejpropracovanější pravidla pro překonání precedentu přirozeně pochází ze států common law právní kultury. Na unijní úrovni se obecně př́liš neuplatní pravidlo, podle něhož může být precedent překonán soudním rozhodnutím vyššího soudu, nebot' instanční nadřízenost a podřizenost se v unijním soudnictví uplatňuje jen omezeně, a to $\mathrm{v}$ prrípadech, kde $\mathrm{v}$ prvním stupni rozhoduje Tribunál, tedy $\mathrm{v}$ prípadech žalob jednotlivců, naproti tomu u rrízení o předběžných otázkách, o porušení povinnosti členským státem nebo řízení o žalobě na neplatnost legislativních aktů, kde je první a poslední instancí Soudní dvůr, se neuplatní vůbec. Soudní dvưr sám svým výkladem vázaný není, precedent tedy může změnit. Změna precedentu se děje meritorním, nikoli procesním rozhodnutím.

\section{Právní moc jako limit efektivního vynucování práva EU}

Význam právní moci v unijním právu spočívá v ještě další rovině a to ve významu právní moci rozhodnutí vnitrostátních soudů ve vztahu k unijnímu právu - právní moc rozsudků vnitrostátních soudů může působit jako limit vynucování unijního práva. Jedná se o situace, kdy je vnitrostátní soudní rozhodnutí rozporné s unijním právem, je však již pravomocné.

Při promýšlení účinků svých rozhodnutí SDEU musí vyvažovat mezi protichůdnými zájmy. Na jedné straně stojí efektivní vymáhání unijního práva, které požaduje v maximální možné míře možnost obnovení řízení (at’ už soudního či správního), pokud bylo dřivější rozhodnutí vydáno v rozporu s unijním právem. Na druhé straně stojí právní moc, podle které je třeba jednou konečně rozhodnutou věc z důvodu zachování právní

69 GERMELMANN, 2009, op. cit., s. 404-414. 
jistoty ponechat v platnosti. Přičemž zásada právní jistoty, stejně jako právní moc, jež je jedním z jejích vyjádření, jsou obecné zásady právní společné právním rádům členských států a tvoří také obecné zásady práva unijního, tedy součást primárního práva. ${ }^{70}$

SDEU uznává procesní autonomii členských států. Jsou-li splněny základní požadavky kladené na národní procesní předpisy, SDEU do nich nezasahuje. Unijní právo především požaduje, aby byly národní předpisy v souladu se zásadami rovnocennosti a efektivity. Vnitrostátní předpisy k uplatňování práv jednotlivce plynoucích z práva EU tedy nesmí být méně př́iznivé než ty, kterými se řídí obdobné situace vnitrostátní povahy, a zároveň nesmí jednotlivci znemožnit domoci se svých práv, ani jejich vymáhání nadměrně ztěžovat. ${ }^{71}$ Pakliže jsou tyto požadavky naplněny, nevyžaduje Soudní dvưr po soudech, aby prolomily právní moc vnitrostátního soudního rozhodnutí, které je v rozporu s unijním právem. ${ }^{72}$

Zásada efektivního vymáhání práva EU tedy není absolutní (na druhou stranu nemá absolutní prioritu ani zásada právní jistoty ${ }^{73}$ ) a SDEU vždy přistupuje $\mathrm{k}$ poměřování chráněných zájmů v konkrétních situacích. Prolomit právní moc je více nakloněný například v př́padech, kdy se jedná o opakované, resp. trvající porušování unijního práva, jako kupř́íkladu ve věci Fallimento ${ }^{74}$, kde by nemožnost prolomit právní moc soudního rozhodnutí vedla k tomu, že by pochybení vnitrostátního soudu spočívající v nesprávném vyhodnocení zneužívajících praktik v oblasti daně z prridané hodnoty nebylo nikdy v budoucnu, v dalších zdaňovacích obdobích možné napravit. Oproti takovýmto stojî př́pady, které jsou spíše nahodilého než systémového charakteru a jejichž řešení nemá přesah mimo daný prrípad. ${ }^{75}$

70 Také viz SOWERY, Katy. Equivalent treatment of Union rights under national procedural law: Târsia. Common Market Law Review, 2016, č. 6, s. 1711-1712.

71 SOWERY, Katy. Equivalent treatment of Union rights under national procedural law: Târsia. Common Market Law Review, 2016, č. 6; nebo rozsudek Soudního dvora (prvního senátu) ze dne 6. ř́jna 2009, Asturcom Telecomunicaciones SL proti Cristina Rodríguez. Nogueira, věc C-40/08, odst. 38.

72 Např. rozsudek Soudního dvora (velkého senátu) ze dne 6. řijna 2015, Dragos Constantin Târsia proti Statul român a Serviciul Public Comunitar Regim Permise de Conducere si Inmatriculare a Autovebiculelor, věc C-69/14; a komentáŕ k němu od SOWERY, Katy. Equivalent treatment of Union rights under national procedural law: Târsia. Common Market Law Review, 2016, č. 6.

$73 \mathrm{~V}$ případě SNUPAT se Soudní dvưr vyjádřil v tom smyslu, že zásada právní jistoty není absolutní a musí být vyvažována se zásadou zákonnosti. Rozsudek Soudního dvora ze dne 22. března 1961, Société nouvelle des usines de Pontlieue - Aciéries du Temple (S.N.U.P.A.T.) proti Vysokému úradu ESUO, spojené věci 42 a $49 / 59$, odst. 87.

74 Rozsudek Soudního dvora (druhého senátu) ze dne 3. září 2009, Amministrazione dell'Economia e delle Finanze a Agenzia delle entrate proti Fallimento Olimpiclub Srl., věc C-2/08.

75 SOWERY, Katy. Equivalent treatment of Union rights under national procedural law: Târsia. Common Market Law Review, 2016, č. 6, s. s. 1719. 


\section{Zásada ne bis in idem}

Zásada ne bis in idem je jedním ze specifických projevů právní moci v oblasti práva trestního a správního práva trestního a jako taková se rovněž v právu EU uplatňuje ${ }^{76}$. Soudní dvưr chápe zásadu ne bis in idem jako zákaz dvojího stíhání a dvojího trestání za jeden skutek. Aplikace této zásady tedy znamená, že je-li vydán zprošt’ující nebo odsuzující rozsudek, nemůže být pro tentýž skutek vedeno nové rízení s cílem uložit další trest. Je-li ovšem rozhodnutí ukládající sankci zrušeno z čistě procesních důvodů, aniž by se zrušující rozhodnutí zabývalo samotným skutkem, není možné na něj hledět jako na zproštění, a následné rízení, prííp. i uložení sankce není v rozporu se zásadou ne bis in idem. V takovém př́padě totiž následné rozhodnutí není druhým rozhodnutím $\mathrm{v}$ téže věci, protože předchozí rozhodnutí nahrazuje. ${ }^{77}$

Jeden skutek (idem) je Soudním dvorem EU definován jako soubor konkrétních skutků, které jsou vzájemně neoddělitelně spojeny ${ }^{78}$. Generální advokát Ruiz-Jarabo Colomer tuto definici výstižně rozvedl tak, že musí být dána ,jednota času, jednota prostoru, ale také jednota úmyslu' a prírozeně se také musí jednat o jednoho pachatele. ${ }^{79}$

Na rozdíl od právní moci má zásada ne bis idem dva základní rozměry - zaprvé působí jako obecný požadavek právní jistoty a zajištění elementární spravedlnosti, který brání tomu, aby se již jednou skončené věci znovu podrobovaly soudnímu přezkumu. Tímto znakem se shoduje s právní mocí. Zadruhé působí jako základní právo jednotlivců, které jednotlivce chrání před tím, aby byli dvakrát postihnuti za tentýž skutek, a chrání tak jejich legitimní očekávání $\mathrm{v}$ prrípadě, že $\mathrm{v}$ řízení $\mathrm{v}$ jejich věci bylo již pravomocně a meritorně rozhodnuto. ${ }^{80}$

Původně v unijním právním řádu tato zásada nijak zakotvena nebyla, podobně jako jiná základní práva si své místo v unijním právu vydobyla skrze judikaturu Soudního dvora EU. Jakým způsobem se tato zásada v judikatuře etablovala, popisuje Sarmiento - v 60 . letech ji ještě Soudní dvůr označoval za ,obecný požadavek přirozeného práva‘ bez bližší

76 Srov. Stanovisko generální advokátky - Kokott - 28 ledna 2010, Evropská komise proti Lucemburskému velkovévodství, věc C-526/08.

77 Rozsudek Soudního dvora ze dne 15. ř́jna 2002, Limburgse Vinyl Maatschappij NV (LVM) (C-238/99 P), DSMNV a DSM Kunststoffen BV (C-244/99 P), Montedison SpA(C-245/99 P), Elf Atochem SA(C-247/99 P), Degussa AG (C-250/99 P), Enichem SpA (C-251/99 P), Wacker-Chemie GmbH a Hoechst AG (C-252/99 P) a Imperial Chemical Industries plc (ICI) (C-254/99 P) proti Komisi Evropských společenství, spojené věci C-238/99 P, C-244/99 P, C-245/99 P, C-247/99 P, C-250/99 P až C-252/99 P a C-254/99 P, odst. 60-62.

78 Rozsudek Soudního dvora (druhého senátu) ze dne 9. března 2006, Trestní ř́zení proti Leopold Henri Van Esbroeck, věc C-436/04, odst. 36.

79 Stanovisko generálního advokáta - Ruiz-Jarabo Colomer - 8 června 2006, Jean Leon Van Straaten proti Staat der Nederlanden a Republiek Italië, věc C-150/05, odst. 77-85.

80 BOCKEL, Bas van. Ne bis in idem in EU law. Cambridge: Cambridge University Press, 2016, s. 13; také Rozsudek Soudního dvora (prvního senátu) ze dne 28. záŕí 2006, Jean Leon Van Straaten proti Staat der Nederlanden a Republiek Italië, věc C-150/05, odst. 59. 
specifikace, později byla vnímána jako součást principu proporcionality v širším smyslu. Od rozsudku Salzgitter je už v právu EU zásada ne bis in idem definitivně vnímána jako samostatná obecná zásada právní. ${ }^{81}$ Každopádně př̀ formulaci a určování účinků této zásady se Soudní dvưr EU inspiroval ustanovením čl. 4 Protokolu č. 7 k Úmluvě o ochraně lidských práv a základních svobod a s ním související judikatury ESLP. $\mathrm{V}$ dnešní době mưžeme říct, že zásada ne bis in idem je coby obecná zásada právní stabilní součástí unijního právního řádu, která našla své výslovné zakotvení v Listině základních práv EU.

\section{Závěr}

Předmětem tohoto článku je fungování právní moci v unijním procesním právu, konkrétně je článek zaměřen především na právní moc rozhodnutí unijních soudů (Soudního dvora a Tribunálu) - její účel, předpoklady a účinky, dále také na některé zvláštnî situace, jako je působení zásady ne bis in idem v unijním právu a na právní moc vnitrostátních soudních rozhodnutí coby limit efektivního vynucování unijního práva. Závěrem z něj plynoucím je, že právní moc, byt' není v předpisech upravujících proces před unijními soudy (Statut SDEU, Jednací řád Soudního dvora a Tribunálu) výslovně zakotvena, je platným institutem unijního práva. Stejně jako její protějšky z vnitrostátních právních řádů má za následek nemožnost soudu rozhodnout ve sporu mezi týmiž účastníky o téže věci. Aby právní moc rozsudku SDEU působila jako přkéážka pro opětovné rozhodnutí ve věci, je nutné, aby se jednalo o tutéž věc - stejnou právní otázku založenou na stejných skutkových okolnostech a aby se jí Soudní dvůr v rozsudku skutečně zabýval, aby tudíž neexistovala jen pouze v podáních stran. Zvláštním projevem právní moci je situace, kdy je právní moc vnitrostátního soudního rozhodnutí vydaného v rozporu s unijním právem - obecně platí, že právní moc rozhodnutí vnitrostátního soudu brání přezkoumání věci, ač je rozhodnutím nastolený stav v rozporu s unijním právem. Je-li však takto vzniklý protiprávní stav nikoli jednotlivý, ale je spíše systémového charakteru a má vliv na větší množství př́ípadů, které nastanou v budoucnu, přikazuje Soudní dvưr právní moc vnitrostátního soudního rozhodnutí prolomit.

81 BOCKEL, 2016, op. cit, s. 108-109; Rozsudek Soudního dvora (pátého senátu) ze dne 2. října 2003, Salzgitter AG proti Komisi Evropských společenství, věc C-182/99 P, odst. 99 a 104. 